\title{
HUBUNGAN PENGETAHUAN DAN DUKUNGAN SUAMI TERHADAP MINAT IBU DALAM MENGGUNAKAN IUD PADA PASANGAN USIA SUBUR DI PUSKESMAS CIPAGERAN TAHUN 2021
}

\author{
Suryani $N^{1}$, Karlina $I^{2}$, Mufti $I R^{3}$

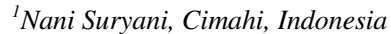 \\ ${ }^{2}$ Intan Karlina, Bandung, Indonesia \\ ${ }^{3}$ Iga Ratia, Bandung, Indonesia
}

\begin{tabular}{l}
\hline ARTICLE INFORMATION \\
\hline Received: October, 14, 2021 \\
Accepted : February, 07, 2022 \\
Available online: February, 08, 2022 \\
KATA KUNCI \\
\hline
\end{tabular}

Pengetahuan, Dukungan Suami, Minat, Penggunaan IUD. CORRESPONDENCE

E-mail: nanisuryani7622@gmail.com

\begin{abstract}
A B S T R A K
IUD merupakan alat kontrasepsi yang efektif dan efisien, nyaman, dan terjangkau. Minat terhadap penggunaan IUD masih rendah dibandingkan kontrasepsi suntik dan pil. Hal tersebut dipengaruhi oleh pengetahuan dan dukungan suami. Tujuan dari penelitian ini untuk mengetahui hubungan pengetahuan dan dukungan suami terhadap minat ibu dalam menggunakan kontrasepsi IUD pada PUS di Puskesmas Cipageran tahun 2021.
\end{abstract}

Metode penelitian menggunakan deskriptif analisis dengan pendekatan cross-sectional. Sampel adalah PUS yang menggunakan kontrasepi di Puskesmas Cipageran pada bulan Juli tahun 2021 sebanyak 176 orang, melalui teknik simple random sampling. Instrumen menggunakan kuesioner. Analisis data menggunakan analisis univariat dan bivariat.

Hasil didapatkan sebagian kecil (46\%) mempunyai minat rendah, sebagian mempunyai pengetahuan rendah $(50,6 \%)$, dan sebagian kecil tidak mendapatkan dukungan suami $(47,2 \%)$. Terdapat hubungan pengetahuan $(\mathrm{p}=0,048)$ dan dukungan suami $(\mathrm{p}=0,000)$ terhadap minat ibu dalam menggunakan kontrasepsi IUD.

Puskesmas diharapkan dapat meningkatkan minat ibu dalam penggunaan IUD melalui program penyuluhan untuk meningkatkan pengetahuan ibu dan dukungan suami.

\section{PENDAHULUAN}

Laju pertumbuhan penduduk yang tidak dapat dikendalikan mengakibatkan banyak dampak terhadap penduduk yaitu menderita kekurangan makanan dan gizi sehingga mengakibatkan tingkat Kesehatan memburuk, mempunyai pendidikan yang rendah, dan banyak penduduk yang pengangguran (BKKBN, 2015). Indonesia masih menduduki urutan ke empat dengan penduduk terbanyak di dunia setelah China, India dan Amerika (World Population Data Sheet, 2015).

Salah satu strategi dari pelaksanaan program keluarga berencana di Indonesia seperti tercantum dalam Rencana Pembangunan Jangka Menengah adalah meningkatnya penggunaan Metode Kontrasepsi Jangka Panjang (MKJP) seperti IUD (Intra Uterine Device), implant dan sterilisasi. Meskipun program penggunaan alat kontrasepsi jangka panjang sudah masuk dalam program pemerintah namun angka pencapaian akseptor keluarga berencana MKJP masih rendah. Penggunaan kontrasepsi masih didominasi oleh alat kontrasepsi jangka pendek terutama suntikan yang mencapai $63,7 \%$, kondom $1,2 \%$ dan pil $17 \%$, sedangkan tingkat pemakaian metode kontrasepsi jangka panjang mencapai $18 \%$ (Kementerian Kesehatan, 2019).

Pentingnya peranan suami dalam mempengaruhi keputusan wanita untuk memakai alat kontrasepsi mempunyai pengaruh yang sangat besar sehingga sebaiknya penyuluhan tentang alat kontrasepsi bukan hanya diberikan kepada ibu-ibu akan tetapi juga kepada pasangannya. Dukungan suami merupakan sifat interaksi yang berlangsung dalam hubungan dengan istri. Sudah menjadi tradisi apabila segala sesuatu harus dengan persetujuan suami. Suami sangat berperan penting dalam pemilihan alat kontrasepsi yang akan di gunakan ibu (Raidanti, 2019).

Data Profil Kesehatan Indonesia tahun 2019, menunjukan jumlah penduduk Jawa Barat terdiri dari 49.316.712 jiwa. Dengan jumlah keseluruhan PUS terdiri dari 7.964.494 jiwa, dan jumlah akseptor KB aktif 5.324.322 jiwa $(66,9 \%)$ yang menggunakan suntik (63,9\%), pil (17,8\%), kondom (0,9\%), implant (5,0\%), IUD $(9,2 \%)$, MOP $(0,4 \%)$, MOW $(2,4 \%)$. Sedangkan untuk akseptor 
KB baru 917.254 jiwa, yang menggunakan suntik $(66,9 \%)$, pil $(17,8 \%)$, kondom $(2,3 \%)$, implant $(5,1 \%)$, IUD $(6,6 \%)$, MOP $(0,2 \%)$, MOW $(1,1 \%)$ (Kemenkes RI, 2019).

Profil Dinas Kesehatan Kota Cimahi Tahun 2019 jumlah penduduk Kota Cimah yaitu 555.966 jiwa, dengan jumlah PUS sebanyak 91.113 jiwa, peserta KB aktif sebanyak 72.897 (79,4\%), akseptor IUD 19.492 (26,7\%), kondom 1733 (2,4\%), suntik $38.204(52,4 \%)$, pil $9.606(13,2 \%)$, MOP $202(0,3 \%)$, MOW $2.791(3,8 \%)$ dan implant $869(1,2 \%)$. Merlis Simon (2018), mengungkapkan bahwa terdapat adanya pengaruh pemberian KIE terhadap penggunaan alat kontrasepsi IUD dan terdapat pengaruh dukungan suami terhadap terhadap penggunaan alat kontrasepsi IUD. Hadriah Oesman (2017), mengungkapkan bahwa Pemakaian kontrasepsi non IUD masih tinggi.

Capaian di wilayah kerja Puskesmas Cipageran yang menggunakan KB IUD yaitu 1.762 orang dari jumlah PUS 8.412 orang yang artinya mencapai $26,2 \%$. Dan untuk peserta KB baru IUD di wilayah Puskesmas Cipageran tahun 2019 yaitu hanya 85 orang. Sedangkan akseptor kondom $211(3,1 \%)$, suntik 3504 $(52,2 \%)$, pil $781(11,6 \%)$, MOP $19(0,3 \%)$, MOW $272(4 \%)$ dan implant 149 (2,2\%). Gerakan KB Nasional selama ini telah berhasil mendorong peningkatan peran serta masyarakat dalam membangun keluarga kecil yang makin mandiri.

Hasil penelitian Ostradela (2019) di BPM Kertapati Palembang tentang faktor yang berhubungan dengan rendahnya minat terhadap kontasepsi IUD, didapatkan sebagian besar responden mempunyai pengetahuan yang kurang baik tentang kontrasepsi IUD (70,7\%), dan sebagian kurang mendapat dukungan suami $(59,8 \%)$. Ada hubungan yang bermakna antara pengetahuan $(\mathrm{p}=0,000)$ dan dukungan suami $(\mathrm{p}=0,000)$ terhadap rendahnya minat IUD.

Berdasarkan latar belakang di atas, maka peneliti ingin mengetahui apakah terdapat hubungan antara pengetahuan dan dukungan suami terhadap minat ibu dalam menggunakan kontrasepsi IUD pada pasangan usia subur di Puskesmas Cipageran tahun 2021.

\section{METODE}

Metode penelitian yang dipilih adalah deskriptif analisis yang meneliti hubungan antara variabel independen dan dependen, yaitu hubungan antara pengetahuan dan dukungan suami terhadap minat ibu dalam menggunakan IUD. Penelitian ini menggunakan pendekatan cross sectional, yaitu pengamatan hanya dilakukan sekali sesuai dengan waktu yang ditentukan oleh peneliti dengan melihat adanya hubungan antara variabel dependen dan independen.

Penelitian ini dilaksanakan pada bulan Juli 2021 dengan populasi bejumlah 313 orang. Pemilihan sampel dilakukan dengan Simple Random Sampling sejumlah 176 responden.

Analisis yang digunakan adalah analisis univariat menggunakan distribusi frekuensi untuk menggambarkan setiap variabel dan analisis bivariat menggunakan uji Chi-Square untuk mengetahui hubungan pengetahuan dan dukungan suami terhadap minat ibu dalam menggunakan kontrasepsi IUD.

\section{HASIL DAN PEMBAHASAN}

Analisis Univariat

Tabel 1 Distribusi Frekuensi Minat Ibu Dalam Menggunakan Kontrasepsi IUD pada Pasangan Usia Subur di Puskesmas Cipageran tahun 2021

\begin{tabular}{|c|c|c|}
\hline Minat Ibu & $\begin{array}{l}\text { Frekuensi } \\
\text { (F) }\end{array}$ & $\begin{array}{c}\text { Persen } \\
(\%)\end{array}$ \\
\hline Tinggi & 95 & 54,0 \\
\hline Rendah & 81 & 46,0 \\
\hline Total & 176 & 100 \\
\hline
\end{tabular}

Hasil analisis pada table 1 di atas menunjukkan bahwa sebagian kecil pasangan usia subur di Puskesmas Cipageran mempunyai minat dalam menggunakan kontrasepsi IUD yang rendah sebesar $46 \%$.

Tabel 2 Distribusi Frekuensi Pengetahuan Pasangan Usia Subur di Puskesmas Cipageran Tahun 2021

\begin{tabular}{|c|c|c|}
\hline Pengetahuan & $\begin{array}{l}\text { Frekuensi } \\
\text { (F) }\end{array}$ & $\begin{array}{c}\text { Persen } \\
(\%)\end{array}$ \\
\hline Baik & 87 & 49,4 \\
\hline Kurang & 89 & 50,6 \\
\hline Total & 176 & 100 \\
\hline
\end{tabular}

Hasil analisis pada tabel 2 di atas menunjukkan bahwa sebagian pasangan usia subur di Puskesmas Cipageran mempunyai pengetahuan kurang tentang penggunaan kontrasepsi IUD sebesar $50,6 \%$.

Tabel 3 Distribusi Frekuensi Dukungan Suami pada Pasangan Usia Subur di Puskesmas Cipageran Tahun 2021

\begin{tabular}{ccc}
\hline Dukungan Suami & $\begin{array}{c}\text { Frekuensi } \\
(\mathbf{F})\end{array}$ & $\begin{array}{c}\text { Persen } \\
(\boldsymbol{\%})\end{array}$ \\
\hline Mendukung & 93 & 52,8 \\
Tidak Mendukung & 83 & 47,2 \\
\hline Total & $\mathbf{1 7 6}$ & $\mathbf{1 0 0}$ \\
\hline
\end{tabular}

Hasil analisis pada tabel 3 di atas menunjukkan bahwa sebagian kecil pasangan usia subur di Puskesmas Cipageran tidak mendapatkan dukungan suami sebesar 47,2\%.

\section{Analisis Bivariat}

Tabel 4 Hubungan Pengetahuan Terhadap Minat Ibu Dalam Menggunakan Kontrasepsi IUD Pada Pasangan Usia Subur di Puskesmas Cipageran Tahun 2021

\begin{tabular}{|c|c|c|c|c|c|c|c|}
\hline \multirow{3}{*}{ Pengetahuan } & \multicolumn{4}{|c|}{ Minat Ibu } & \multirow{2}{*}{\multicolumn{2}{|c|}{ Total }} & \multirow{3}{*}{ P-Value } \\
\hline & \multicolumn{2}{|c|}{ Tinggi } & \multicolumn{2}{|c|}{ Rendah } & & & \\
\hline & $\mathbf{F}$ & $\%$ & $\mathbf{F}$ & $\%$ & $\mathbf{N}$ & $\%$ & \\
\hline Baik & 54 & 62,1 & 33 & 37,9 & 87 & 100 & \\
\hline Kurang & 41 & 46,1 & 48 & 53,9 & 89 & 100 & 0,048 \\
\hline Total & 95 & 54,0 & 81 & 46,0 & 176 & 100 & \\
\hline
\end{tabular}

Berdasarkan Tabel 4 dapat dilihat bahwa lebih dari setengah pasangan usia subur di Puskesmas Cipageran yang mempunyai minat rendah, sebesar 59,3\% mempunyai pengetahuan rendah. Hasil uji statistik didapatkan hubungan pengetahuan terhadap minat ibu dalam menggunakan kontrasepsi IUD pada pasangan usia subur di Puskesmas Cipageran tahun 2021 dengan pvalue $=0,048(<0,05)$. 
Tabel 5 Hubungan Dukungan Suami Terhadap Minat Ibu Dalam Menggunakan Kontrasepsi IUD Pada Pasangan Usia Subur di Puskesmas Cipageran Tahun 2021

\begin{tabular}{|c|c|c|c|c|c|c|c|}
\hline \multirow{3}{*}{ Dukungan Suami } & \multicolumn{4}{|c|}{ Minat Ibu } & \multirow{2}{*}{\multicolumn{2}{|c|}{ Total }} & \multirow{3}{*}{ P-Value } \\
\hline & \multicolumn{2}{|c|}{ Tinggi } & \multicolumn{2}{|c|}{ Rendah } & & & \\
\hline & $\mathbf{F}$ & $\%$ & $\mathbf{F}$ & $\%$ & $\mathbf{N}$ & $\%$ & \\
\hline Mendukung & 68 & 73,1 & 25 & 26,9 & 93 & 100 & \\
\hline $\begin{array}{l}\text { Tidak } \\
\text { Mendukung }\end{array}$ & 27 & 32,5 & 56 & 67,5 & 83 & 100 & $\mathbf{0 , 0 0 0}$ \\
\hline Total & 95 & 54.0 & 81 & 46,0 & 176 & 100 & \\
\hline
\end{tabular}

Berdasarkan Tabel 5 dapat dilihat bahwa sebagian besar pasangan usia subur di Puskesmas Cipageran yang mempunyai minat rendah, sebanyak 69,1\% tidak mendapatkan dukungan 2021 dengan p-value $=0,048(<0,05)$. Tingkat pengetahuan responden bagus tentang kontrasepsi IUD dan memahami betul, seharusnya mereka memilih kontrasepsi IUD karena tingkat kegagalan sangat sedikit di bandingkan dengan kontrasepsi pil dan suntik. Penyebab lain rendah nya penggunaan IUD yaitu rasa ketakutan dan kekhawatiran responden akan pemasangan (IUD).

Berdasarkan hasil penelitian dapat dilihat bahwa lebih dari setengah pasangan usia subur di Puskesmas Cipageran yang mempunyai minat rendah, sebesar 53,9 \% mempunyai pengetahuan rendah. Hasil uji statistik didapatkan hubungan pengetahuan terhadap minat ibu dalam menggunakan kontrasepsi IUD pada pasangan usia subur di Puskesmas Cipageran tahun 2021 dengan $p$-value $=0,048 \quad(<0,05)$. Tingkat pengetahuan responden bagus tentang kontrasepsi IUD dan memahami betul, seharusnya mereka memilih kontrasepsi IUD karena tingkat kegagalan sangat sedikit di bandingkan dengan kontrasepsi pil dan suntik. Penyebab lain rendah nya penggunaan IUD yaitu rasa ketakutan dan kekhawatiran responden akan pemasangan (IUD).

\section{SIMPULAN}

Berdasarkan hasil penelitian, analisis data dan pembahasan mengenai hubungan pengetahuan dan dukungan suami terhadap minat ibu dalam menggunakan kontrasepsi IUD pada pasangan usia subur di Puskesmas Cipageran tahun 2021, dapat disimpulkan bahwa:

a. Sebagian kecil pasangan usia subur di Puskesmas Cipageran mempunyai minat yang rendah dalam menggunakan kontrasepsi IUD.

b. Sebagian pasangan usia subur di Puskesmas Cipageran mempunyai pengetahuan rendah.

c. Sebagian kecil pasangan usia subur di Puskesmas Cipageran tidak mendapatkan dukungan suami.

d. Terdapat hubungan pengetahuan terhadap minat ibu dalam menggunakan kontrasepsi IUD pada pasangan usia subur di Puskesmas Cipageran tahun 2021.

e. Terdapat hubungan dukungan suami terhadap minat ibu dalam menggunakan kontrasepsi IUD pada pasangan usia subur di Puskesmas Cipageran tahun 2021.

\section{UCAPAN TERIMA KASIH}

Terima Kasih kepada LPPM Institut Kesehatan Rajawali Bandung atas dukungan dalam penyusunan jurnal ini.

\section{DAFTAR PUSTAKA}

[1] BKKBN. Pedoman Pengelolaan Puat Informasi dan Konseling Remaja dan Mahasiswa PIK Remaja/Mahasiswa. Badan Kependudukan dan Keluarga Berencana Nasional. Jakarta. 2012.

[2] _. Keluarga Berencana dan Kontrasepsi. Badan Kependudukan dan Keluarga Berencana Nasional. Jakarta. 2015

[3] Kemenkes RI. Profil Kesehatan Indonesia Tahun 2019. Jakarta: Pusat Data dan Informasi Kementerian Kesehatan Republik Indonesia. 2019

[4] Profil Dinas Kesehatan Kota Cimahi Tahun 2019

[5] Raidanti, D. "Hubungan Pengetahuan dan Dukungan Suami Dengan Pemakaian Kontrasepsi KB IUD Intra Uterine Device di wilayah kerja Puskesmas Salembaran Jaya Kabupaten Tangerang”. JKFT, vol. 4, no. 1, 2019. [Online]. Tersedia:

http://jurnal.umt.ac.id/index.php/jkft/article/view/2016/1244 [Accessed Mei. 10, 2021]

[6] Ostradela, M dan Miranti, "Faktor yang berhubungan dengan rendahnya minat terhadap kontrasepsi IUD di BPM Kertapati," JKSP, vol. 2, no. 2, Agustus 2019. [Online]. Available: http://ojs.ukmc.ac.id/index.php/JOH [Accessed Mei. 05, 2021].

[7] Sugiyono. Metode Penelitian Kuantitatif, Kualitatif, dan $R \& D$. Penerbit Alfabeta Bandung. 2017

[8] World Population Data Sheet. 2015 World Data Sheet with a Special Focus on Women's Empowerment. Population Reference Bureau. 2015

[9] Kemenkes RI. Profil Kesehatan Indonesia Tahun 2019. Jakarta: Pusat Data dan Informasi Kementerian Kesehatan Republik Indonesia. 2019 